\title{
Water Resources of Concordia Parish, Louisiana
}

\section{Introduction}

Information concerning the availability, use, and quality of water in Concordia Parish, Louisiana (fig. 1 ), is critical for proper water-supply management. The purpose of this fact sheet is to present information that can be used by water managers, parish residents, and others for stewardship of this vital resource. Information on the availability, past and current use, use trends, and water quality from groundwater and surface-water sources in the parish is presented. Previously published reports (see References Cited section) and data stored in the U.S. Geological Survey's National Water Information System (U.S. Geological Survey, 2016) are the primary sources of the information presented here.
In 2010, over 50 million gallons per day (Mgal/d) of water were withdrawn in Concordia Parish, including about 28.7 Mgal/d from groundwater sources and 22.3 Mgal/d from surface-water sources ${ }^{1}$ (table 1). Withdrawals for agricultural use, composed of livestock, rice irrigation, general irrigation, and aquaculture accounted for about 77 percent $(39.2 \mathrm{Mgal} / \mathrm{d})$ of the total water withdrawn (table 2). Other categories of use included public supply, power generation, and rural domestic. Water-use data collected at 5-year intervals from 1960 to 2010 indicated that water withdrawals peaked in 2010 (fig. 2).

${ }^{1}$ Water-withdrawal data are based on estimated or reported site-specific data and aggregated data, which are distributed to sources. For a full description of water-use estimate methodology, see "Data Collection" in Sargent (2011). Tabulation of numbers in text and tables may result in different totals because of rounding; nonrounded numbers are used for calculation of totals.

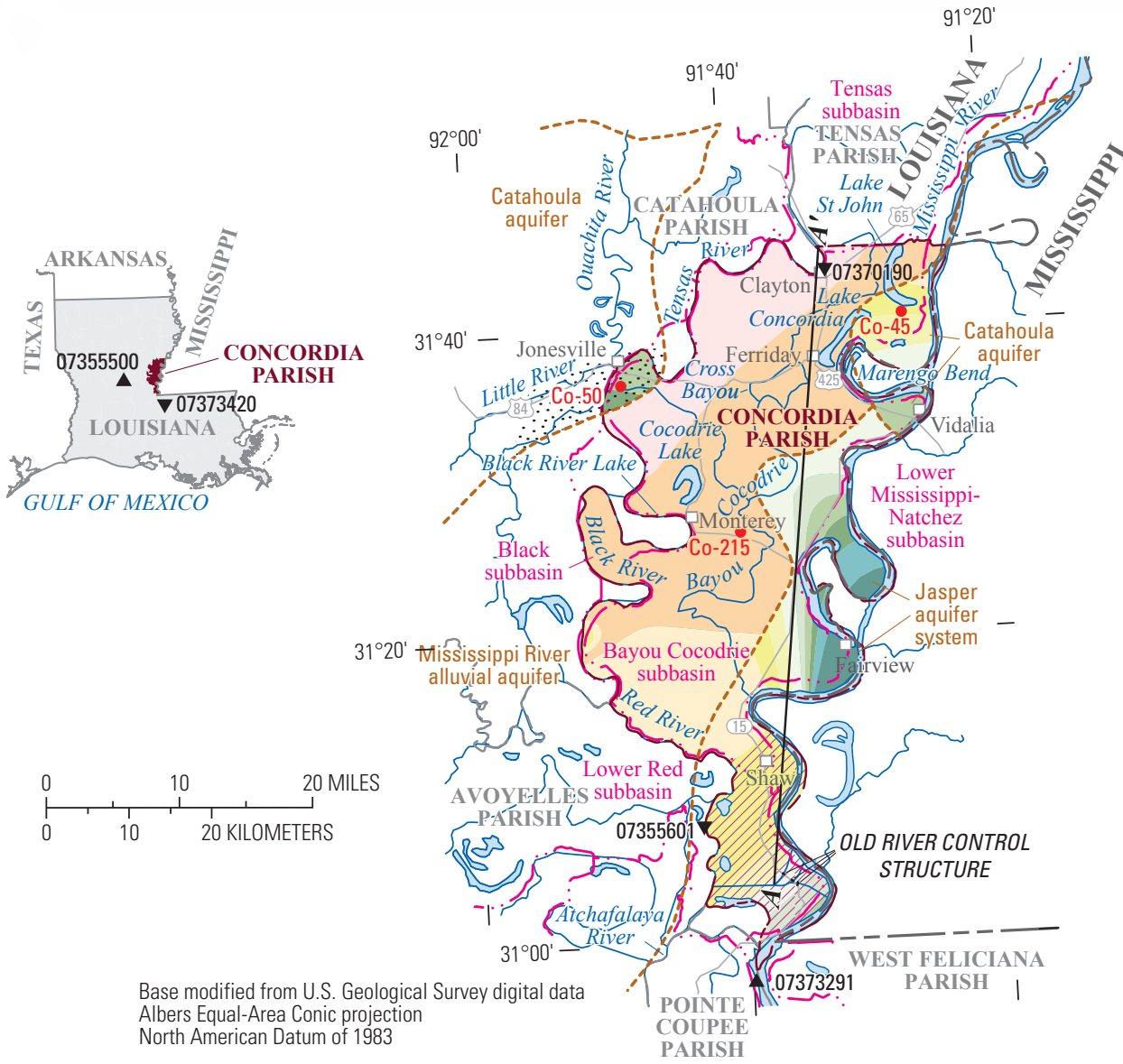

\section{EXPLANATION}

Approximate altitude of base of fresh groundwater, in feet below National Geodetic Vertical Datum of 1929 (NGVD 29) (modified from Smoot 1988)-Deepest freshwater contained within the alluvial aquifer, except where noted 50 to 99 100 to 149

150 to 199

200 to 299

300 to 399

400 to 499

500 to 599

600 to 699

700 to 799

800 to 999

1,000 to 1,299

1,300 and deeper

Area where data indicate that aquifers may contain freshwater at depths greater than shown by Smoot, 1988

Area where intermediate sands contain saltwater

- - - - - Approximate boundary of area showing deepest freshwater contained within underlying Jasper aquifer system and Catahoula aquifer

- ..- River subbasin boundary

$A-A^{\prime}$ Line of section (see fig. 3)

$\bullet \quad$ Well for which hydrograph is shown Co-50 (see fig. 4)

U.S. Geological Survey surface-water

07373291 discharge site and number

$\nabla$

U.S. Geological Survey surface-water quality site and number (see table 4)

Figure 1. Location of study area, Concordia Parish, Louisiana. 
Table 1. Water withdrawals, in million gallons per day, by source in Concordia Parish, Louisiana, 2010 (B.P. Sargent, U.S. Geological Survey, written commun., 2015).

\begin{tabular}{lcc}
\hline $\begin{array}{c}\text { Aquifer, aquifer system, } \\
\text { or surface-water body }\end{array}$ & Groundwater & $\begin{array}{c}\text { Surface } \\
\text { water }\end{array}$ \\
\hline $\begin{array}{l}\text { Mississippi River } \\
\text { alluvial aquifer }\end{array}$ & 26.16 & \\
Jasper aquifer system & 2.17 & \\
Catahoula aquifer & 0.41 & \\
Bayou Cocodrie & & 9.14 \\
Cross Bayou & & 2.95 \\
Marengo Bend & & 1.50 \\
Mississippi River & & 8.26 \\
Miscellaneous streams & & 0.41 \\
Total & $\mathbf{2 8 . 7 4}$ & $\mathbf{2 2 . 2 5}$ \\
\hline
\end{tabular}

Table 2. Water withdrawals, in million gallons per day, by use category in Concordia Parish, Louisiana, 2010 (Sargent, 2011).

\begin{tabular}{lccc}
\hline \multicolumn{1}{c}{ Use category } & Groundwater & Surface water & Total \\
\hline Public supply & 2.00 & 1.50 & 3.50 \\
Power generation & 0.00 & 8.26 & 8.26 \\
Rural domestic & 0.06 & 0.00 & 0.06 \\
Livestock & 0.10 & 0.02 & 0.11 \\
Rice irrigation & 10.81 & 10.81 & 21.62 \\
General irrigation & 14.08 & 1.56 & 15.64 \\
Aquaculture & 1.70 & 0.10 & 1.80 \\
\cline { 2 - 4 } Total & $\mathbf{2 8 . 7 4}$ & $\mathbf{2 2 . 2 5}$ & $\mathbf{5 0 . 9 9}$ \\
\hline
\end{tabular}

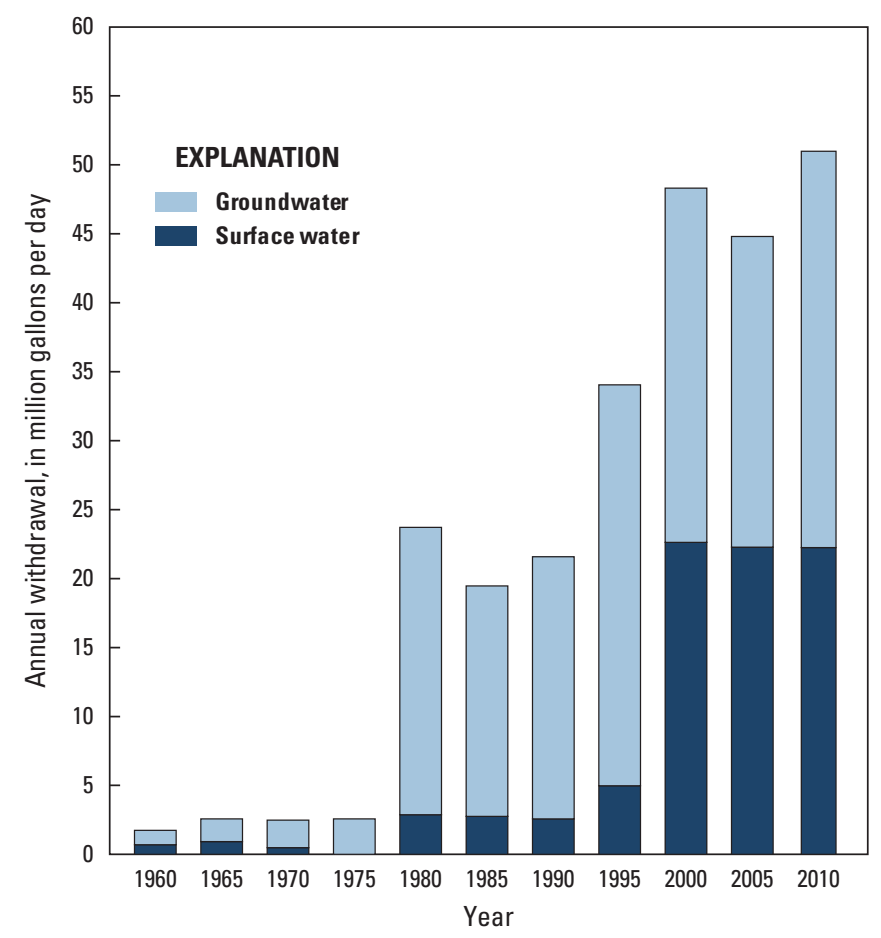

Figure 2. Water withdrawals in Concordia Parish, Louisiana, 1960-2010 (Sargent, 2011).

\section{Groundwater Resources}

The primary freshwater-bearing aquifer in Concordia Parish is the Mississippi River alluvial aquifer. Other aquifers with freshwater underlying Concordia Parish include the Jasper aquifer system (fig. 3) and Catahoula aquifer (fig. 1). In the western part of the parish, the base of fresh groundwater (water with a chloride concentration of 250 milligrams per liter [mg/L] or less) is present in the Mississippi River alluvial aquifer at depths ranging from about 50 feet (ft) to about $200 \mathrm{ft}$ below the National Geodetic Vertical Datum of 1929 (NGVD 29) (fig. 1). In the eastern part of the parish, the base of fresh groundwater is present in the Jasper aquifer system or Catahoula aquifer at depths ranging from less than $200 \mathrm{ft}$ to $1,000 \mathrm{ft}$ below NGVD 29 (fig. 1) (Smoot, 1988). Saltwater (water with a chloride concentration that exceeds $250 \mathrm{mg} / \mathrm{L}$ ) is present in some localized areas above the base of freshwater (fig.1; Seanor and Smoot, 1995).

\section{Mississippi River Alluvial Aquifer}

The Mississippi River alluvial aquifer extends across all of Concordia Parish and is composed of the coarser part of sediments deposited primarily by the Mississippi River. These deposits generally grade from clay and silt at the surface to coarse sand and gravel at the base. The Mississippi River alluvial deposit thickness ranges from less than $140 \mathrm{ft}$ to greater than $200 \mathrm{ft}$ within the parish. The base of the aquifer ranges from shallower than 80 $\mathrm{ft}$ below NGVD 29 in the northern part of the parish to greater than $160 \mathrm{ft}$ below NGVD 29 near the southern tip of the parish (Whitfield, 1975).

The primary source of recharge for the alluvial aquifer is the infiltration of precipitation with secondary sources of recharge from streams and rivers during high stage. Water generally moves southward in the alluvial aquifer. Groundwater discharges naturally by way of flow into streams and rivers and evapotranspiration, and artificially by way of well withdrawals (Whitfield, 1975).

In 1990, water levels in wells screened in the Mississippi River alluvial aquifer ranged from less than $50 \mathrm{ft}$ above NGVD 29 in the northern part of the parish to about $30 \mathrm{ft}$ above NGVD 29 in the southern part of the Parish (Seanor and Smoot, 1995). Water levels at well Co-215, located in the central part of the parish, have fluctuated annually less than about $10 \mathrm{ft}$ and remained relatively stable during 1989-2015 (fig. 4). Water levels at well Co-45, located in the northeastern part of the parish near Lake St. John, fluctuated annually during 2012-2016, but show little change overall since the well was drilled in 1968.

State well-registration records listed 383 active water wells screened in the Mississippi River alluvial aquifer in Concordia Parish in 2015, including 309 irrigation wells, 64 domestic wells, and 10 public-supply wells. Depths of these wells ranged from 45 to $235 \mathrm{ft}$ below land surface, and reported yields ranged from 8 to 3,400 gallons per minute (gal/min) (Louisiana Department of Natural Resources, written commun., 2015). In 2010, about 26.2 Mgal/d were withdrawn from the aquifer, with use categories including $0.15 \mathrm{Mgal} / \mathrm{d}$ for public supply, $0.05 \mathrm{Mgal} / \mathrm{d}$ for rural domestic, $0.09 \mathrm{Mgal} / \mathrm{d}$ for livestock, $10.38 \mathrm{Mgal} / \mathrm{d}$ for rice irrigation, $13.80 \mathrm{Mgal} / \mathrm{d}$ for general irrigation, and $1.70 \mathrm{Mgal} / \mathrm{d}$ for aquaculture (B.P. Sargent, U.S. Geological Survey, written commun., 2015). 


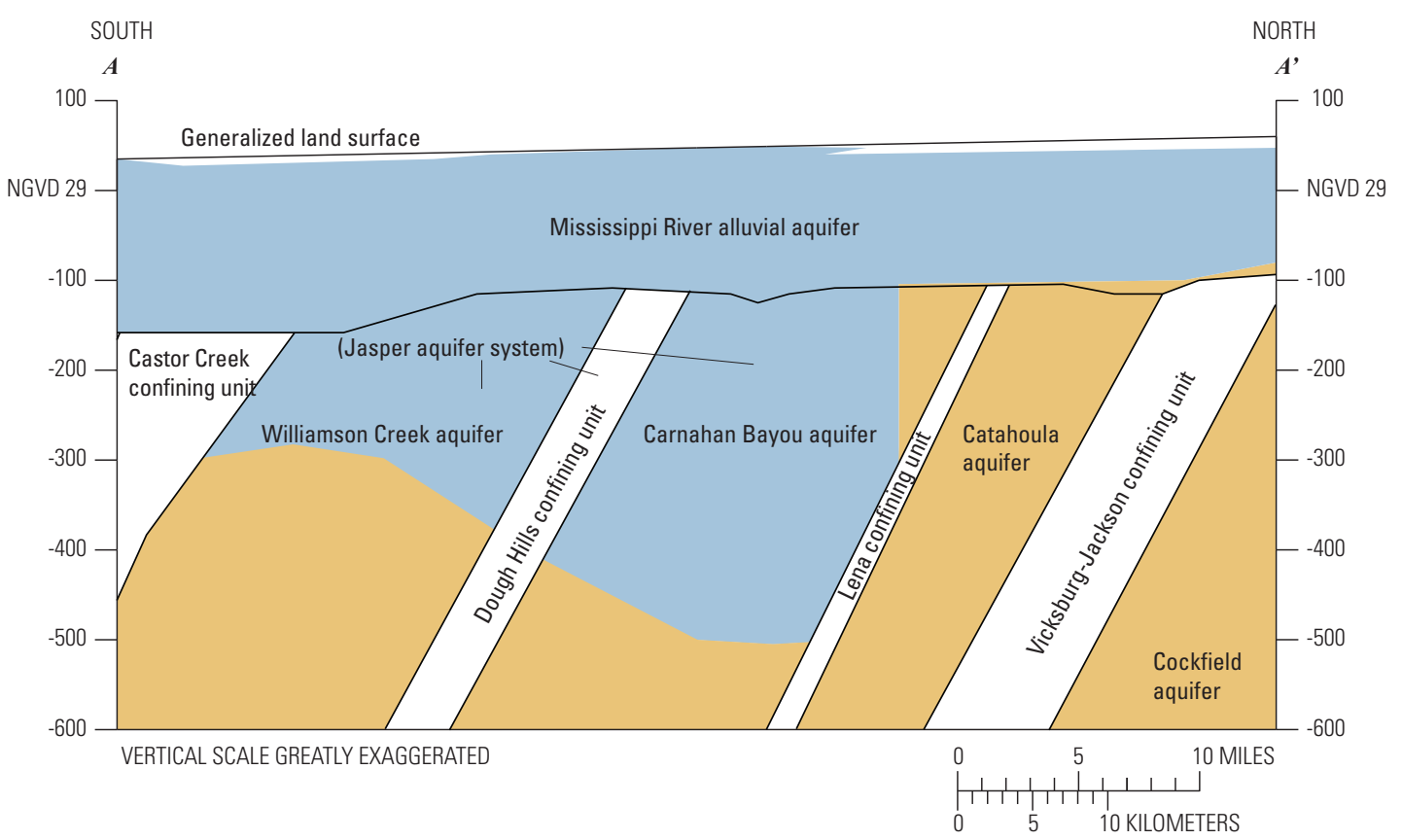

EXPLANATION

Freshwater in aquifer

Saltwater in aquifer-Saltwater contains greater than 250 milligrams per liter chloride
Figure 3. Idealized south-tonorth hydrogeologic section through Concordia Parish, Louisiana, showing aquifer and confining layer intervals (individual sand and clay layers not shown; modified from Whitfield, 1975, and Smoot, 1988, 1989). Trace of section shown on figure 1 .

\section{Jasper Aquifer System and Catahoula Aquifer}

The Jasper aquifer system is composed of the Williamson Creek aquifer, the Dough Hills confining unit, and the Carnahan Bayou aquifer (fig. 3; Martin and others, 1988). In Concordia Parish, freshwater in these aquifers is only available in a less than 10-mile-wide band along the Mississippi River (fig. 1) and is recharged by precipitation in southwestern Mississippi (Martin and others, 1988; Smoot, 1988).

The Catahoula aquifer underlies all of Concordia Parish but contains freshwater only in the northeastern and northwestern parts of the parish (fig. 1). The aquifer is composed of sands that are typically white to light gray, range from very coarse to very fine grained, are seldom areally extensive, and are interbedded with silts and clays. Recharge to the aquifer is provided by the infiltration of precipitation and flow from underlying aquifers (Martin and Whiteman, 1986; Fendick and Carter, 2015). In 2013, water levels in two wells screened in the Catahoula aquifer, one near Jonesville and the other at the southern end of Lake St. John were about zero and $40 \mathrm{ft}$ above NGVD 29, respectively (Fendick and Carter, 2015). Water levels in the Catahoula aquifer at well Co-50 (fig. 1) declined about $50 \mathrm{ft}$ from 1972 to 2015 (fig. 4).

State well-registration records listed 28 active water wells screened in the Jasper aquifer system and Catahoula aquifer in Concordia Parish in 2015, including 6 domestic, 3 industrial, 3 irrigation, and 16 public supply. Depths of these wells ranged from 275 to $765 \mathrm{ft}$ below land surface, and reported yields ranged from 15 to $1,070 \mathrm{gal} / \mathrm{min}$ (Louisiana Department of Natural Resources, written commun., 2015). In 2010, about $2.58 \mathrm{Mgal} / \mathrm{d}$ were withdrawn from the Jasper aquifer system and Catahoula aquifer, with use categories including 1.85 $\mathrm{Mgal} / \mathrm{d}$ for public supply, $0.008 \mathrm{Mgal} / \mathrm{d}$ for rural domestic, 0.01 $\mathrm{Mgal} / \mathrm{d}$ for livestock, $0.43 \mathrm{Mgal} / \mathrm{d}$ for rice irrigation, and 0.28 $\mathrm{Mgal} / \mathrm{d}$ for general irrigation (B.P. Sargent, U.S. Geological Survey, written commun., 2015).

\section{Groundwater Quality}

Groundwater samples taken from the Mississippi River alluvial, Carnahan Bayou, and Catahoula aquifers were found to be within the U.S. Environmental Protection Agency's Secondary Maximum Contaminant Levels ${ }^{2}$ (SMCLs) for $\mathrm{pH}$ and sulfate (table 3 ). Median hardness was within the very hard ${ }^{3}$ range for the Mississippi River alluvial aquifer and within the soft range for the Carnahan Bayou and Catahoula aquifers. Iron and manganese concentrations were in excess of SMCLs for over 90 percent of samples in the Mississippi River alluvial and Carnahan Bayou aquifers.

\section{Surface-Water Resources}

Numerous surface-water resources in Concordia Parish are present in three regional drainage basins and flow in a general southerly direction. The Lower Mississippi-Natchez Basin (Hydrologic Unit Code [HUC] 080601) and co-located, co-named subbasin (HUC 08060100) drain the land adjacent to the Mississippi River (fig. 1). The Boeuf-Tensas Basin (HUC 080500) contains the Tensas subbasin (HUC 08050003) and drains a relatively small area of land that is roughly adjacent to the Tensas River in the northern part of the parish (fig. 1). The majority of the parish is drained by the Lower Red Basin (HUC 080403), which is subdivided into three subbasins within Concordia Parish, including the Bayou Cocodrie subbasin (HUC 08040306), Black subbasin (HUC 08040305), and the Lower Red subbasin (HUC 08040301) (fig. 1) (U.S. Geological Survey, 2016). Numerous canals, control structures, and levees have modified the natural state of these resources.

${ }^{2}$ The SMCLs are nonenforceable Federal guidelines regarding cosmetic effects (such as tooth or skin discoloration), aesthetic effects (such as taste, odor, or color), or technical effects (such as damage to water equipment or reduced effectiveness of treatment for other contaminants) of drinking water. SMCLs were established as guidelines by the U.S. Environmental Protection Agency (2016).

${ }^{3}$ Hardness ranges, expressed as milligrams per liter of calcium carbonate, are as follows: $0-60$, soft; $61-120$, moderately hard; $121-180$, hard; greater than 180 , very hard (Hem, 1985). 


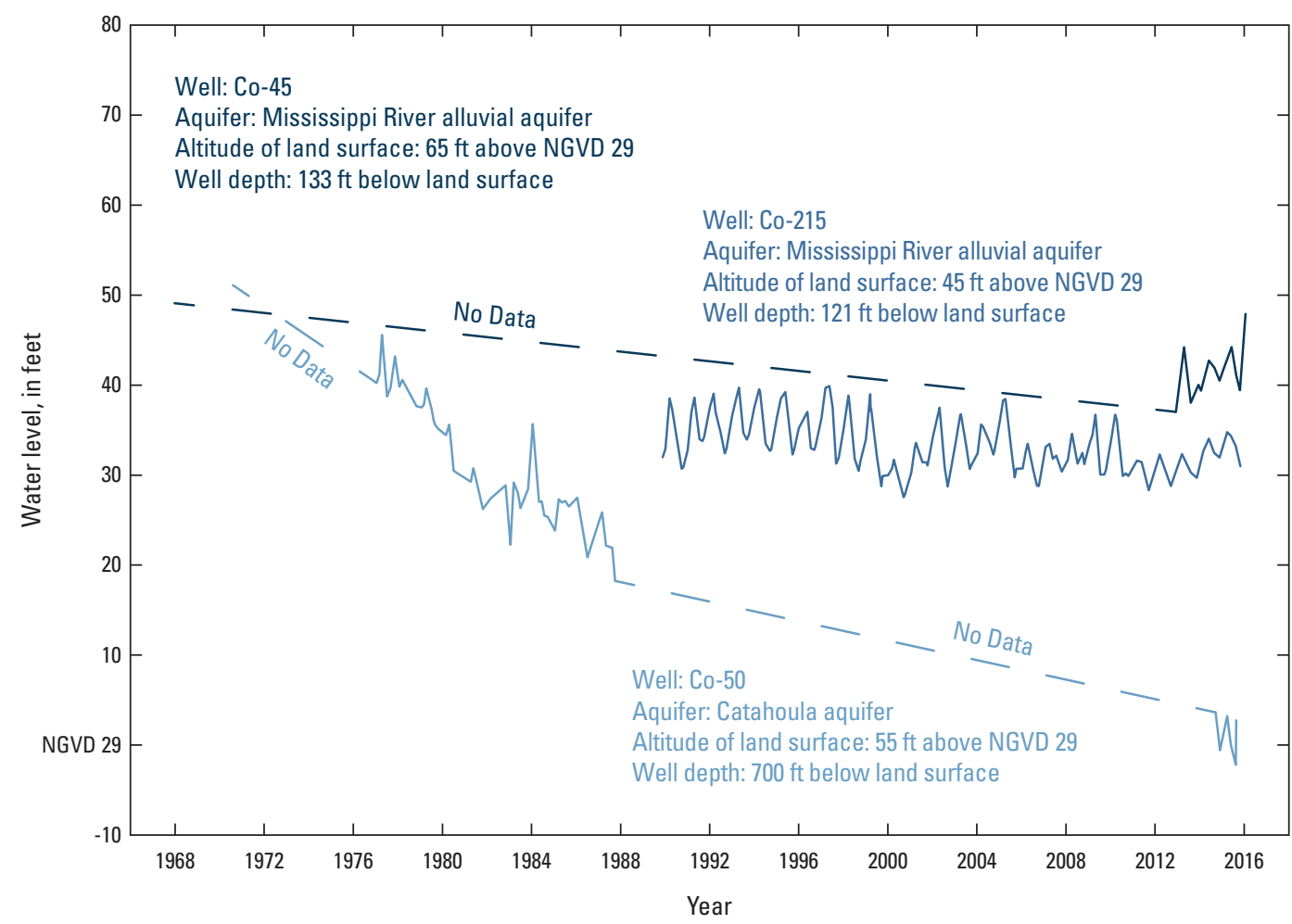

Figure 4. Water levels in well Co-45 and Co-215 screened in the Mississippi River alluvial aquifer and well $\mathrm{Co}_{0}-50$ screened in the Catahoula aquifer in Concordia Parish, Louisiana (see fig. 1 for well locations; U.S. Geological Survey, 2016). Land surface and water levels are in feet (ft) relative to the National Geodetic Vertical Datum of 1929 (NGVD 29).

\section{Lower Mississippi-Natchez and Boeuf-Tensas Basins}

The Mississippi River is sustained by drainage from over 40 percent of the conterminous United States but drains little land area in Concordia Parish because of levees along the river. The average flow of the Mississippi River near Red River Landing, near the southern tip of Concordia Parish (site number 07373291; fig. 1), was about 460,000 cubic feet per second $\left(\mathrm{ft}^{3} / \mathrm{s}\right.$ ) for the period 1928-76 (Wells, 1980; Demcheck and others, 2004). The Old River Control Structure, located in the southern part of the parish (fig. 1), directs approximately 30 percent of the combined flow of the Mississippi River and Red River above the structure to the Atchafalaya River (U.S. Army Corps of Engineers, 2009). In 2010, 8.26 Mgal/d were withdrawn from the Mississippi River for power generation, and $1.50 \mathrm{Mgal} / \mathrm{d}$ from the Marengo Bend oxbow lake for public supply (table 1). An additional $0.39 \mathrm{Mgal} / \mathrm{d}$ was withdrawn from miscellaneous streams for general irrigation (B.P. Sargent, U.S. Geological Survey, written commun., 2015).

The Boeuf-Tensas Basin includes a reach of the Tensas River that forms the northwestern border of the parish. The Tensas River and subbasin end near Jonesville where the Tensas River merges with the Ouachita River and Little River to form the Black River (fig. 1).

\section{Lower Red Basin}

The Bayou Cocodrie subbasin occupies the majority of the surface area of Concordia Parish and is drained primarily by Bayou Cocodrie, which originates near Ferriday, flows through the parish, and empties into the Red River near the southern tip of the parish. In 2010, $9.14 \mathrm{Mgal} / \mathrm{d}$ of water were withdrawn from Bayou Cocodrie for rice irrigation $(7.89 \mathrm{Mgal} / \mathrm{d})$, general irrigation $(1.17 \mathrm{Mgal} / \mathrm{d})$, and aquaculture $(0.08 \mathrm{Mgal} / \mathrm{d})$. In addition, $2.95 \mathrm{Mgal} / \mathrm{d}$ of water were withdrawn from Cross Bayou for rice irrigation (2.92 Mgal/d) and aquaculture $(0.03 \mathrm{Mgal} / \mathrm{d})$ and $0.02 \mathrm{Mgal} / \mathrm{d}$ of water were withdrawn from miscellaneous streams for livestock (B.P. Sargent, U.S. Geological Survey, written commun., 2015).

The Black subbasin contains the Black River which serves as the southwestern border of the parish until emptying into the Red River. The Lower Red subbasin contains the Red River which forms part of the boundary of the southern tip of the parish and eventually merges with Mississippi River water diverted from the Old River Control Structure to form the Atchafalaya River (fig. 1). The average discharge of the Red River upstream from Concordia Parish at Alexandria (site number 07355500; fig. 1 index map) was 30,770 ft $3 / \mathrm{s}$ during 1928-82 (Carlson and others, 1983).

Several lakes are present within or bordering these subbasins including Cocodrie Lake, Black River Lake, Lake Concordia, and Lake St. John. Recreational watersports, fishing, and swimming are popular on these lakes (Louisiana Wildlife and Fisheries, 2016).

\section{Surface-Water Quality}

Water samples collected from the Mississippi River near St. Francisville (site number 07373420; fig. 1 index map) during 1954-2013, Tensas River at Clayton (site number 07370190) during 1968-91, and Red River near Simmesport (site number 07355601) during 1977-86 (fig. 1) were found to be generally within SMCLs for $\mathrm{pH}$ and concentrations of chloride, sulfate, iron, and dissolved solids (table 4). Median hardness values were within the hard range in the Mississippi River and within the moderately hard range in the Tensas River and Red River. Median values for dissolved-oxygen concentrations were greater than $7 \mathrm{mg} / \mathrm{L}$, whereas $5 \mathrm{mg} / \mathrm{L}$ is considered the minimum value for a diverse population of fresh, warmwater biota, including sport fish (Louisiana Department of Environmental Quality, 2008).

Upstream activities affect the quality of Mississippi River water available to the parish. Concentrations of constituents such as agricultural pesticides and nutrients, are generally highest in late spring-early summer, commonly referred to as the "spring flush," which results from the runoff of upstream applications of these pesticides and nutrients (Demcheck and others, 2004). Suspendedsediment concentrations are generally highest in late winter and early spring and lowest in late summer and fall (Wells, 1980). 
Table 3. Summary of selected freshwater-quality characteristics for the Mississippi River alluvial, Carnahan Bayou, and Catahoula aquifers in Concordia Parish, Louisiana (U.S. Geological Survey, 2016).

[Values are in milligrams per liter, except as noted. $\mu \mathrm{S} / \mathrm{cm}$, microsiemen per centimeter; ${ }^{\circ} \mathrm{C}$, degree Celsius; $\mathrm{SU}$, standard unit; $\mathrm{CaCO}_{3}, \mathrm{calcium}$ carbonate; $\mu \mathrm{g} / \mathrm{L}$, microgram per liter; <, less than; SMCL, Secondary Maximum Contaminant Level established by the U.S. Environmental Protection Agency (2016);

NA, not applicable]

\begin{tabular}{|c|c|c|c|c|c|c|c|c|c|c|}
\hline $\begin{array}{c}\text { Specific } \\
\text { conduc- } \\
\text { tance, } \\
\text { field ( } \mathrm{S} \text { / } \\
\mathrm{cm}\end{array}$ & $\begin{array}{l}\mathrm{pH}, \\
\text { field } \\
\text { (SU) }\end{array}$ & $\begin{array}{c}\text { Hard- } \\
\text { ness (as } \\
\mathrm{CaCO}_{3} \text { ) }\end{array}$ & $\begin{array}{l}\text { Calcium, } \\
\text { filtered } \\
\text { (as Ca) }\end{array}$ & $\begin{array}{c}\text { Mag- } \\
\text { nesium, } \\
\text { filtered } \\
\text { (as Mg) }\end{array}$ & $\begin{array}{l}\text { Sodium, } \\
\text { filtered } \\
\text { (as } \mathrm{Na} \text { ) }\end{array}$ & $\begin{array}{l}\text { Chlo- } \\
\text { ride, } \\
\text { filtered } \\
\text { (as Cl) }\end{array}$ & $\begin{array}{c}\text { Sulfate, } \\
\text { filtered } \\
\text { (as } \\
\mathrm{SO}_{4} \text { ) }\end{array}$ & $\begin{array}{c}\text { Iron, } \\
\text { filtered, } \\
\text { in } \mu \mathrm{g} / \mathrm{L} \\
\text { (as Fe) }\end{array}$ & $\begin{array}{c}\text { Man- } \\
\text { ganese, } \\
\text { filtered, } \\
\text { in } \mu \mathrm{g} / \mathrm{L} \\
\text { (as Mn) }\end{array}$ & $\begin{array}{c}\text { Dis- } \\
\text { solved } \\
\text { solids, } \\
\text { filtered }\end{array}$ \\
\hline
\end{tabular}

\begin{tabular}{lrrrrrrrrrrrr}
\hline \multicolumn{10}{c}{ Mississippi River alluvial aquifer, 1941-2015 (47 wells) } \\
\hline Median & 893 & 7.1 & 400 & 100 & 33.5 & 33 & 28 & 12.5 & 10,650 & 690 & 528 \\
10th percentile & 773 & 6.8 & 249.6 & 72.4 & 22.3 & 15.0 & 8.0 & $<0.2$ & 5,950 & 194.2 & 425.8 \\
90th percentile & 1,250 & 7.8 & 480.2 & 120 & 43.2 & 81.2 & 141.8 & 30.3 & 16,000 & 1,336 & 729.6 \\
Number of samples & 81 & 34 & 40 & 33 & 33 & 28 & 103 & 30 & 20 & 17 & 25 & \\
$\begin{array}{l}\text { Percentage of samples } \\
\quad \text { that do not exceed }\end{array}$ & NA & 100 & NA & NA & NA & NA & 100 & 100 & 5 & 6 \\
$\quad$ SMCLs & & & & & & & & &
\end{tabular}

\begin{tabular}{|c|c|c|c|c|c|c|c|c|c|c|c|}
\hline \multicolumn{12}{|c|}{ Carnahan Bayou aquifer, 1941-83 (13 wells) } \\
\hline Median & 632 & 7.2 & 16 & 4.5 & 1.2 & 120 & 12 & 5.4 & 895 & 205 & 406 \\
\hline 10th percentile & 527 & 7.0 & 4.6 & 1.2 & $<0.1$ & 73 & 7.0 & $<0.4$ & 494 & 79 & 351.1 \\
\hline Number of samples & 13 & 13 & 17 & 13 & 13 & 13 & 17 & 16 & 8 & 4 & 12 \\
\hline $\begin{array}{l}\text { Percentage of samples } \\
\text { that do not exceed } \\
\text { SMCLs }\end{array}$ & NA & 100 & NA & NA & NA & NA & 100 & 100 & 0 & 0 & 75 \\
\hline
\end{tabular}

\begin{tabular}{|c|c|c|c|c|c|c|c|c|c|c|c|}
\hline \multicolumn{12}{|c|}{ Catahoula aquifer, 1969-83 (10 wells) } \\
\hline 10th percentile & 411.5 & 7.5 & 1.9 & 0.5 & 0.1 & 97.4 & 42.4 & $<0.4$ & 29 & $<10$ & 302.8 \\
\hline Number of samples & 10 & 10 & 10 & 10 & 10 & 10 & 10 & 10 & 10 & 9 & 10 \\
\hline $\begin{array}{l}\text { Percentage of samples } \\
\text { that do not exceed } \\
\text { SMCLs }\end{array}$ & NA & 100 & NA & NA & NA & NA & 100 & 100 & 80 & 78 & 80 \\
\hline
\end{tabular}

\begin{tabular}{llllllllllll}
\hline \multicolumn{10}{c}{ SMCLs } \\
\hline NA & $6.5-8.5$ & NA & NA & NA & NA & 250 & 250 & 300 & 50 & 500 \\
\hline
\end{tabular}

\section{References Cited}

Carlson, D.D., Stallworth, G.R., Dantin, L.J., and Stuart, C.G., 1983, Water resources data, Louisiana, water year 1983: U.S. Geological Survey Water-Data Report LA-83-1.

Demcheck, D.K.; Tollett, R.W.; Mize, S.V.; Skrobialowski, S.C.; Fendick, R.B., Jr.; Swarzenski, C.M.; and Porter, Stephen, 2004, Water quality in the AcadianPontchartrain Drainages, Louisiana and Mississippi, 1999-2001: U.S. Geological Survey Circular 1232, 41 p. [Also available at http://pubs.water.usgs.gov/cir1232.]

Fendick, R.B., Jr., and Carter, Kayla, 2015, Potentiometric surface of the Catahoula aquifer in central Louisiana, 2013: U.S. Geological Survey Scientific Investigations Map 3339, 1 sheet, accessed February 19, 2016, at http://dx.doi.org/10.3133/sim3339.

Hem, J.D., 1985, Study and interpretation of the chemical characteristics of natural water (3d ed.): U.S. Geological Survey Water-Supply Paper 2254, 264 p., accessed February 20, 2013, at http://pubs.er.usgs.gov/publication/wsp2254.

Louisiana Department of Environmental Quality, 2008, Environmental Regulatory Code, Title 33, Part IX, Subpart 1: Baton Rouge, Louisiana Department of Environmental Quality, accessed June 9, 2009, at http:www.deq.louisiana.gov/portal/tabid/1674/ Default.aspx.

Louisiana Wildlife and Fisheries, 2016, Waterbody management plans_-Inland: Louisiana Wildlife and Fisheries Web page, accessed February 4, 2016, at http://www.wlf. louisiana.gov/fishing/waterbody-management-plans-inland.
Martin, Angel, Jr., and Whiteman, C.D., Jr., 1986, Generalized potentiometric surface of the Catahoula aquifer in central Louisiana, 1980: U.S. Geological Survey Water-Resources Investigations Report 86-4059, 1 pl.

Martin, Angel, Jr.; Whiteman, C.D., Jr.; and Becnel, M.J., 1988, Generalized potentiometric surfaces of the upper and lower Jasper and equivalent aquifers in Louisiana, 1984: U.S. Geological Survey Water-Resources Investigations Report 87-4139, 2 pls., accessed February 19, 2016, at https://pubs.er.usgs.gov/publication/wri874139.

Sargent, B.P., 2011, Water use in Louisiana, 2010: Louisiana Department of Transportation and Development Water Resources Special Report no. 17, 135 p.

Seanor, R.C., and Smoot, C.W., 1995, Louisiana ground-water map no. 6-Potentiometric surface, 1990, and water-level changes, 1974-90, of the Mississippi River alluvial aquifer in northeastern Louisiana: U.S. Geological Survey Water-Resources Investigations Report 95-4146, 2 sheets.

Smoot, C.W., 1988, Louisiana hydrologic atlas map no. 3-Altitude of the base of freshwater in Louisiana: U.S. Geological Survey Water-Resources Investigations Report 86-4314, 1 sheet, accessed November 2, 2011, at http://pubs.er.usgs.gov/publication/ wri864150.

Smoot, C.W., 1989, Louisiana hydrologic atlas map no. 4 - Geohydrologic sections of Louisiana: U.S. Geological Survey Water-Resources Investigations Report 87-4288, sheet, accessed February 10, 2012, at http://pubs.er.usgs.gov/publication/wri874288.

U.S. Army Corps of Engineers, 2009, Old River Control brochure: U.S. Army Corps of Engineers New Orleans District, accessed March 9, 2016, at http://www.mvn.usace. army.mil/Portals/56/docs/PAO/Brochures/OldRiverControlBrochure.pdf. 
Table 4. Summary of selected water-quality characteristics for the Mississippi River near St. Francisville, Tensas River at Clayton, and Red River near Simmesport, Louisiana (U.S. Geological Survey, 2016).

[Values are in milligrams per liter, except as noted. $\mu \mathrm{S} / \mathrm{cm}$, microsiemen per centimeter; ${ }^{\circ} \mathrm{C}$, degree Celsius; $\mathrm{SU}$, standard unit; $\mathrm{CaCO}_{3}$, calcium carbonate; $\mu \mathrm{g} / \mathrm{L}$, microgram per liter; <, less than; E, estimated; SMCL, Secondary Maximum Contaminant Level established by the U.S. Environmental Protection Agency (2016); NA, not applicable]

\begin{tabular}{|c|c|c|c|c|c|c|c|c|c|c|}
\hline $\begin{array}{c}\text { Specific } \\
\text { conduc- } \\
\text { tance, } \\
\text { field } \\
(\mu \mathrm{S} / \mathrm{cm} \\
\left.\text { at } 25^{\circ} \mathrm{C}\right)\end{array}$ & $\begin{array}{l}\text { Oxygen, } \\
\text { dis- } \\
\text { solved }\end{array}$ & $\begin{array}{l}\mathrm{pH}, \\
\text { field } \\
\text { (SU) }\end{array}$ & $\begin{array}{l}\text { Hard- } \\
\text { ness (as } \\
\mathrm{CaCO}_{3} \text { ) }\end{array}$ & $\begin{array}{c}\text { Calcium, } \\
\text { filtered } \\
\text { (as Ca) }\end{array}$ & $\begin{array}{l}\text { Mag- } \\
\text { nesium, } \\
\text { filtered } \\
\text { (as Mg) }\end{array}$ & $\begin{array}{l}\text { Sodium, } \\
\text { filtered } \\
\text { (as Na) }\end{array}$ & $\begin{array}{l}\text { Chlo- } \\
\text { ride, } \\
\text { fil- } \\
\text { tered } \\
\text { (as Cl) }\end{array}$ & $\begin{array}{l}\text { Sulfate, } \\
\text { filtered } \\
\text { (as } \mathrm{SO}_{4} \text { ) }\end{array}$ & $\begin{array}{l}\text { Iron, } \\
\text { filtered, } \\
\text { in } \mu \text { g/L } \\
\text { (as Fe) }\end{array}$ & $\begin{array}{l}\text { Dis- } \\
\text { solved } \\
\text { solids, } \\
\text { filtered }\end{array}$ \\
\hline
\end{tabular}

\begin{tabular}{|c|c|c|c|c|c|c|c|c|c|c|c|}
\hline \multicolumn{12}{|c|}{ Mississippi River near St. Francisville, 1954-2013¹ } \\
\hline Median & 378 & 8.6 & 7.7 & 140 & 39 & 11.7 & 18 & 20 & 47 & $<12.6$ & 230 \\
\hline 10th percentile & 290 & 6.5 & 7.2 & 110 & 31.7 & 8.6 & 11.4 & 14 & 33.7 & $\mathrm{E}<6$ & 178 \\
\hline Number of samples & 841 & 529 & 982 & 966 & 666 & 670 & 584 & 976 & 974 & 511 & 1,231 \\
\hline $\begin{array}{l}\text { Percentage of } \\
\text { samples that do } \\
\text { not exceed SMCLs }\end{array}$ & NA & NA & 100 & NA & NA & NA & NA & 100 & 100 & 100 & 100 \\
\hline
\end{tabular}

\begin{tabular}{|c|c|c|c|c|c|c|c|c|c|c|c|}
\hline \multicolumn{12}{|c|}{ Tensas River at Clayton, 1968-91² } \\
\hline Median & 292 & 7.9 & 7.3 & 110 & 28 & 9 & 15 & 18 & 11 & 25 & 168 \\
\hline 10th percentile & 123 & 5.6 & 6.5 & 42 & 12 & 3 & 4 & 4 & 6 & $<10$ & 86.8 \\
\hline Number of samples & 58 & 35 & 58 & 58 & 58 & 58 & 58 & 58 & 58 & 10 & 58 \\
\hline $\begin{array}{l}\text { Percentage of } \\
\text { samples that do } \\
\text { not exceed SMCLs }\end{array}$ & NA & NA & 90 & NA & NA & NA & NA & 100 & 100 & 100 & 100 \\
\hline
\end{tabular}

\begin{tabular}{|c|c|c|c|c|c|c|c|c|c|c|c|}
\hline \multicolumn{12}{|c|}{ Red River near Simmesport, 1977-8633 } \\
\hline 10th percentile & 158 & 5.5 & 6.6 & 42 & 12 & 3 & 12 & 18 & 13 & 20 & 98 \\
\hline Number of samples & 79 & 78 & 79 & 76 & 76 & 76 & 76 & 78 & 78 & 35 & 77 \\
\hline $\begin{array}{l}\text { Percentage of } \\
\text { samples that do } \\
\text { not exceed SMCLs }\end{array}$ & NA & NA & 92 & NA & NA & NA & NA & 100 & 100 & 94 & 90 \\
\hline \multicolumn{12}{|c|}{ SMCLs } \\
\hline & NA & NA & $6.5-8.5$ & NA & NA & NA & NA & 250 & 250 & 300 & 500 \\
\hline
\end{tabular}

${ }^{1}$ Site number 07373420 (see fig. 1).

${ }^{2}$ Site number 07370190 (see fig. 1).

${ }^{3}$ Site number 07355601 (see fig. 1).

U.S. Environmental Protection Agency, 2016, Secondary Drinking Water Standards: Guidance for Nuisance Chemicals, accessed April 13, 2016, at https://www.epa.gov/ dwstandardsregulations/secondary-drinking-water-standards-guidance-nuisancechemicals.

U.S. Geological Survey, 2016, National Water Information System-Web interface, accessed September 28, 2016, at http://dx.doi.org/10.5066/F7P55KJN.

Wells, F.C., 1980, Hydrology and water quality of the lower Mississippi River: Louisiana Department of Transportation and Development, Office of Public Works Water Resources Technical Report no. 21, 83 p. [Also available at http://la.water.usgs.gov/ publications/pdfs/TR21.pdf.]

Whitfield, M.S., Jr., 1975, Geohydrology and water quality of the Mississippi River alluvial aquifer, northeastern Louisiana: Louisiana Department of Public Works Water Resources Technical Report no. 10, 29 p. [Also available at http://la.water.usgs.gov/ publications/pdfs/TR10.pdf.]
This fact sheet was published by the U.S. Geological Survey in cooperation with the Louisiana Department of Transportation and Development.

\section{By Vincent E. White}

\section{For additional information, contact:}

Director, USGS Lower Mississippi-Gulf Water Science Center 3535 S. Sherwood Forest Blvd., Suite 120

Baton Rouge, LA 70816

E-mail: gs-w-lmg_center_director@usgs.gov

Fax: (225) 298-5490

Telephone: (225) 298-5481

Home Page: http://la.water.usgs.gov 